\title{
Spatiotemporal Hotspots and Decadal Evolution of Extreme Rainfall-Induced Landslides: Case Studies in Southern Taiwan
}

\author{
Chunhung $\mathrm{Wu}$ * and Chengyi Lin
}

check for updates

Citation: Wu, C.; Lin, C. Spatiotemporal Hotspots and Decadal Evolution of Extreme Rainfall-Induced Landslides: Case Studies in Southern Taiwan. Water 2021, 13, 2090. https://doi.org/ $10.3390 /$ w13152090

Academic Editor: Su-Chin Chen

Received: 29 June 2021

Accepted: 27 July 2021

Published: 30 July 2021

Publisher's Note: MDPI stays neutral with regard to jurisdictional claims in published maps and institutional affiliations.

Copyright: (c) 2021 by the authors. Licensee MDPI, Basel, Switzerland. This article is an open access article distributed under the terms and conditions of the Creative Commons Attribution (CC BY) license (https:// creativecommons.org/licenses/by/ $4.0 /)$.
Department of Water Resources Engineering and Conservation, Feng Chia University, Taichung 40724, Taiwan; jknokiajk88@yahoo.com.tw

* Correspondence: chhuwu@fcu.edu.tw; Tel.: +886-424517250-3223

\begin{abstract}
The 2009 Typhoon Morakot triggered numerous landslides in southern Taiwan, and the landslide ratios in the Ailiao and Tamali river watershed were $7.6 \%$ and $10.7 \%$, respectively. The sediment yields from the numerous landslides that were deposited in the gullies and narrow reaches upstream of Ailiao and Tamali river watersheds dominated the landslide recovery and evolution from 2010 to 2015. Rainfall records and annual landslide inventories from 2005 to 2015 were used to analyze the landslide evolution and identify the landslide hotspots. The landslide recovery time in the Ailiao and Tamali river watershed after 2009 Typhoon Morakot was estimated as 5 years after 2009 Typhoon Morakot. The landslide was easily induced, enlarged, or difficult to recover during the oscillating period, particularly in the sub-watersheds, with a landslide ratio $>4.4 \%$. The return period threshold of rainfall-induced landslides during the landslide recovery period was $<2$ years, and the landslide types of the new or enlarged landslide were the bank-erosion landslide, headwater landslide, and the reoccurrence of old landslide. The landslide hotspot areas in the Ailiao and Tamali river watershed were 2.67-2.88 times larger after the 2009 Typhoon Morakot using the emerging hot spot analysis, and most of the new or enlarged landslide cases were identified into the oscillating or sporadic or consecutive landslide hotspots. The results can contribute to developing strategies of watershed management in watersheds with a dense landslide.
\end{abstract}

Keywords: landslide evolution; spatiotemporal cluster analysis; landslide hotspots

\section{Introduction}

Landslides induced by large earthquakes or extreme rainfall events have been the main reason for disasters in the past two decades in Taiwan. Typhoon Morakot in 2009 dumped around $2000 \mathrm{~mm}$ of rainfall in 3 days in southern Taiwan [1], resulting in severe landslide-related disasters, including the catastrophic deep-seated Xiaolin landslide [2] and the following dam failure [3]. Over a decade since the 2009 Typhoon Morakot, sedimentrelated disaster events still occurred in the Kaoping River watershed in southern Taiwan. Although most landslides in southern Taiwan had been gradually recovered, the hillslope was still under high landslide susceptibility.

The rate and location of landslide recovery after the large earthquake or extreme rainfall events play essential roles in developing the watershed management strategies for watersheds with a dense landslide. The landslide recovery in the watersheds with dense landslides after large earthquake events is related to the earthquake magnitude, geological settings, and fault distribution and characteristics [4-6], while recovery after extreme rainfall events were mostly related to the distribution of drainage network [7]. The sediment yield from landslides or debris flow in the watersheds with dense landslides is usually the dominant factor behind the geomorphologic evolution, particularly in the upstream watershed. The randomly deposited sediment in narrow upstream reaches usually results in rivers gradually becoming sinuous and inducing bank-erosion landslides. Sediment from bank-erosion landslides usually increases the sinuosity of narrow reaches and changes the geomorphology of the river in the upstream watershed. 
Long-term geomorphologic landslide evolution in watersheds is strongly related to spatiotemporal landslide distribution [8], which can be observed using the spatiotemporal cluster analysis with the high-resolution digital elevation model (DEM) and multi-annual landslide inventories $[4,6]$. Several researchers have discussed the changes in the distribution and activeness of landslides after extreme rainfall-induced [7] or earthquakeinduced [5,8-11] events and found that the spatiotemporal distribution and activeness of landslides were key factors behind the geomorphologic evolution of watersheds. Identifying landslide hotspots and cold spots using multi-annual landslide inventories can help researchers analyze landslide activeness and recovery after large earthquake-induced landslide disasters [12].

The space-time cluster analysis (abbreviated as spatiotemporal cluster analysis) in ArcGIS Pro software [13] is a useful analysis tool that can describe data's spatial and temporal distribution patterns. This tool had been used to analyze the spread of the COVID19 virus [14], road traffic accident occurrences [15], and the spread of air pollution [4,16] in recent years. Landslide disaster studies using the spatiotemporal cluster analysis have focused on discussing the long-term spatiotemporal distribution of disasters $[5,8]$ and analyzing the relationship between disaster occurrence and related factors $[6,9,17,18]$. Spatiotemporal cluster analysis with multi-annual landslide inventories after extreme rainfall events can contribute to determining landslide hotspots and cold spots, identify locations where the landslide recovery was difficult, and analyze the reasons behind these factors. The use of spatiotemporal cluster analysis to observe landslide evolution trends and identify landslide clustering locations is more effective than only the spatial or temporal analysis of landslides.

The 2009 Typhoon Morakot (from 6-10 August 2009) caused the most severe rainfallinduced disaster event in the past two decades in Taiwan, and the return period accumulated 24 and $48 \mathrm{~h}$ of rainfall during the 2009 Typhoon Morakot in southern Taiwan exceeded $200 \mathrm{y}$ [1]. The extreme rainfall event also caused numerous landslides and severe debris flow in southern Taiwan, and the landslide ratio (i.e., the ratio of the landslide area to watershed area) in the four sub-watersheds of the Kaoping River watershed after the typhoon exceeded 6.5\% [1]. The geomorphologic evolution and developing trends of watersheds with dense landslides after 2009 Typhoon Morakot (abbreviated as after 2009) in southern Taiwan are worthy of discussion. The Ailiao river watershed (abbreviated as $A R W$ ) and Tamali river watershed (abbreviated as $T R W$ ) were the watersheds with the highest landslide ratio in southeastern and southwestern Taiwan after 2009. The $A R W$ and $T R W$ were selected to observe the landslide evolution from 2005 to 2015 and identify the landslide hotspots and cold spots using the spatiotemporal cluster analysis. The evolution characteristic of extreme rainfall-induced landslide events in Taiwan was also compared with that of large earthquake-induced landslide events in the world, and the cluster location and reason of new or enlarged landslides in the following years after 2009 were analyzed in the study.

\section{Research Areas}

\subsection{Ailiao River Watershed (ARW)}

The Ailiao river watershed (abbreviated as $A R W$ ) is located in southwestern Taiwan (Figures 1 and 2), and the area is $623.3 \mathrm{~km}^{2}$. The average elevation and average slope in the $A R W$ are $1006 \mathrm{~m}$ and $30.5^{\circ}$. The average annual precipitation is $3716 \mathrm{~mm}$ based on the records of six rainfall stations from 2005 to 2015 in the neighborhood of $A R W$ (Figure 2a). The average precipitation in the rainy seasons, i.e., from May to October, occupies $>90 \%$ of the average annual precipitation. The land use distribution in the $A R W$ is dominated by forest, which occupies $80.8 \%$ of the total watershed area. The main geological settings in the $A R W$ consist of the Chaochou Formation, the Pilushan Formation, the Alluvium, and the Kaoling Schist (Figure 2b). The total precipitation during the 2009 Typhoon Morakot in the ARW was $2977 \mathrm{~mm}$, i.e., around 80\% of the average annual precipitation. The 2995 landslide cases (Figure 2a) were induced by the 2009 
Typhoon Morakot in the $A R W$, and the landslide ratio, i.e., the ratio of the landslide area to the watershed area, was estimated as $7.6 \%$. The landslides after 2009 centralized in the northeast $A R W$, especially in the A01 $\left(8.2 \mathrm{~km}^{2}\right), \mathrm{A} 02\left(6.7 \mathrm{~km}^{2}\right), \mathrm{A} 03\left(2.5 \mathrm{~km}^{2}\right), \mathrm{A} 07\left(3.2 \mathrm{~km}^{2}\right)$, and A11 $\left(9.5 \mathrm{~km}^{2}\right)$ sub-watersheds (Figure $2 \mathrm{~b}$ ). The occupied percentage of the landslide cases with area $>100,000 \mathrm{~m}^{2}, 1000-100,000 \mathrm{~m}^{2}$, and $<1000 \mathrm{~m}^{2}$ to all landslide cases in 2009 in the $A R W$ were $3.5 \%, 73.0 \%$, and $23.0 \%$, respectively. The relation between the landslide length to width ratio and the mean slope in the ARW is shown in Figure 3; 93.1\% and $57.6 \%$ of the landslide cases in 2009 in the $A R W$ were of the landslide length to width ratio $>1.0$ and ranged from 1.0 to 5.0. The rainfall-triggered slides, including the rotational and translational slides and flows on the hillslope with the slope $>30$ degree, were the main landslide types in the $A R W$.

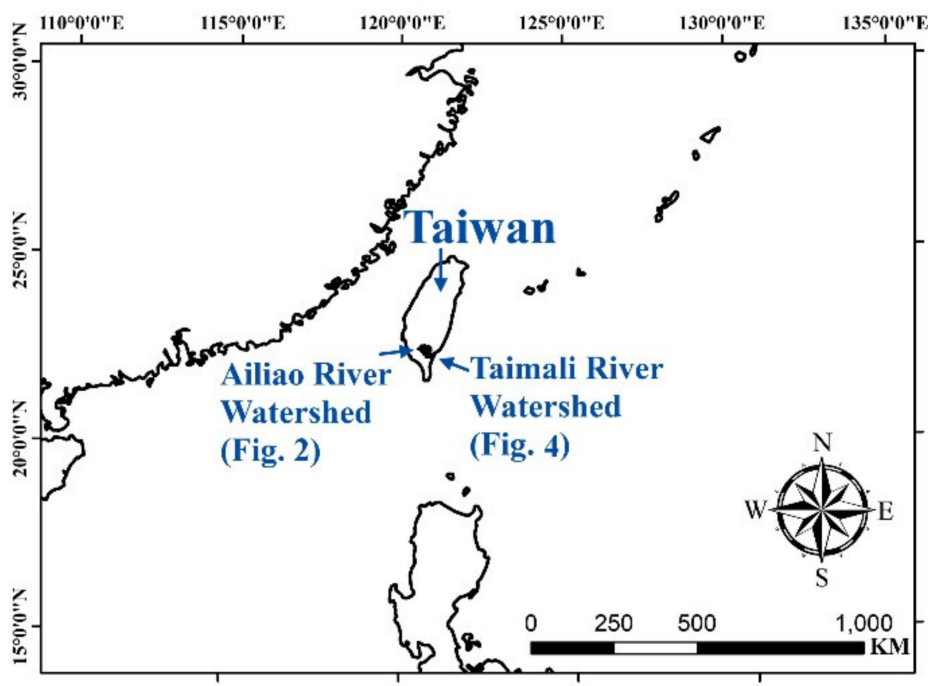

Figure 1. Location of Taiwan, Ailiao river watershed (abbreviated as ARW), and Taimali river watershed (abbreviated as TRW).
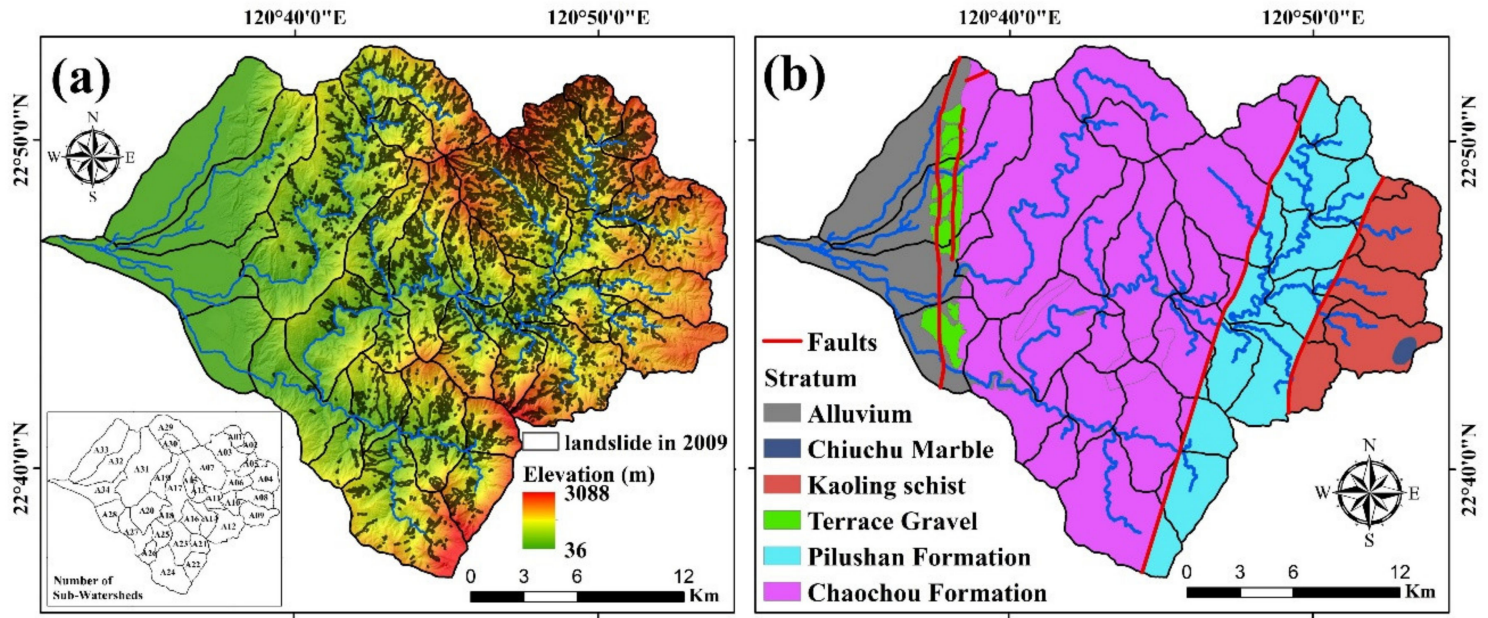

Figure 2. The distribution of elevation, landslide after 2009 Typhoon Morakot, and sub-watersheds (a), geological settings (b), in the $A R W$. 


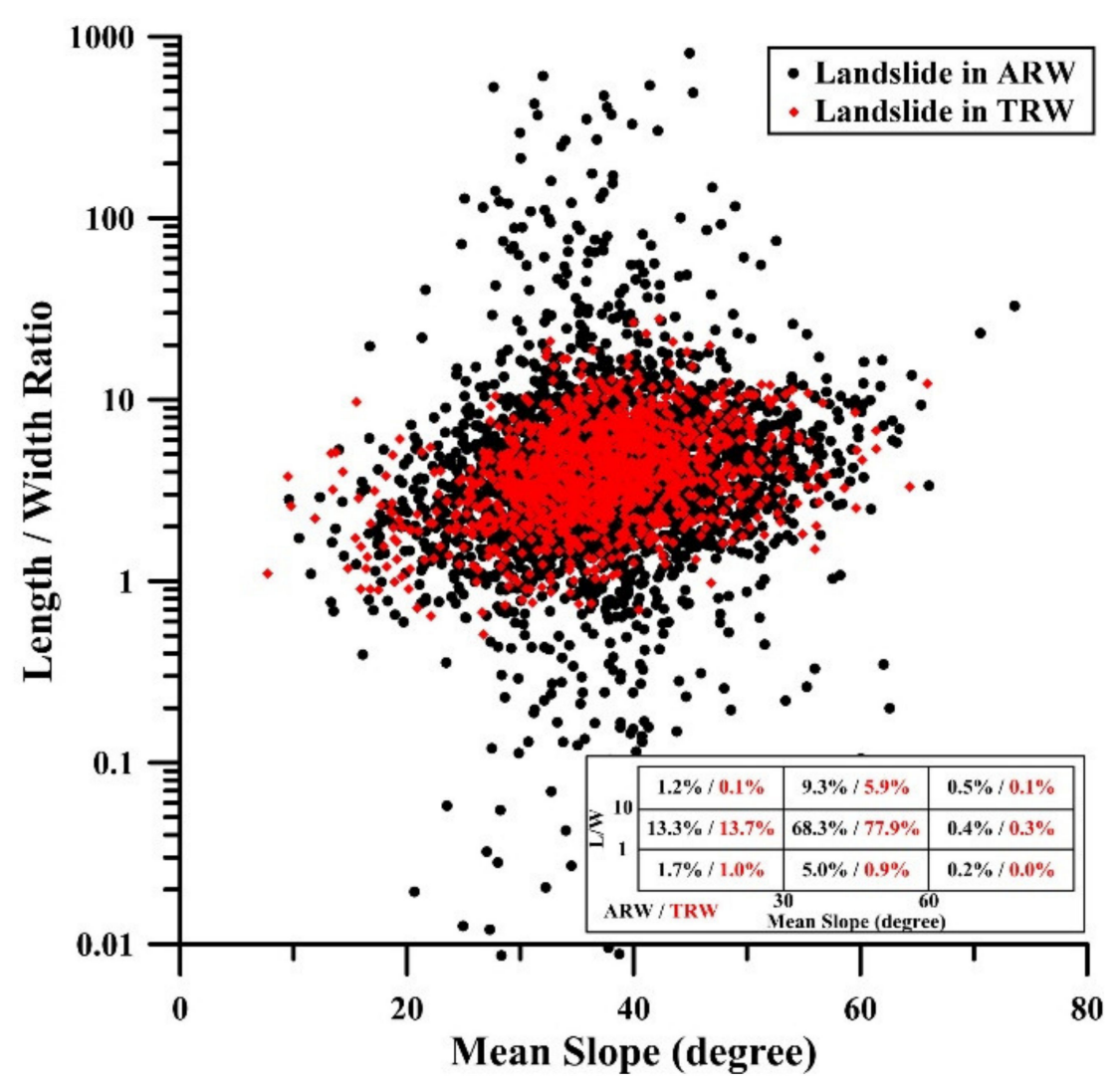

Figure 3. Relationship between the ratio of landslide length to width and mean slope of the landslide cases induced by 2009 Typhoon Morakot in the ARW and TRW.

\subsection{Taimali River Watershed (TRW)}

The Taimali River Watershed (abbreviated as TRW) is located in southeastern Taiwan (Figures 1 and 4) and the area is $264.9 \mathrm{~km}^{2}$. The average elevation and slope in the TRW are $789.4 \mathrm{~m}$ and $30.4^{\circ}$, respectively. The average annual precipitation is $2185 \mathrm{~mm}$ based on the records of five rainfall stations from 2005 to 2015 in the neighborhood of TRW (Figure 4a). The average precipitation in the rainy seasons, i.e., from May to October, occupies $76 \%$ of the average annual precipitation. The land use distribution in the TRW consists of forest $(81.59 \%)$, agricultural land $(9.12 \%)$, water conservancy $(4.32 \%)$, and others. The main geological settings in the TRW consist of three main strata, including the Chaochou Formation, the Pilushan Formation, and the Alluvium (Figure 4b). The total precipitation during the 2009 Typhoon Morakot in the TRW was $932.5 \mathrm{~mm}$, i.e., around $42.7 \%$ of the average annual precipitation. The 1283 landslide cases (Figure 4a) were induced by 2009.

Typhoon Morakot in the $T R W$, and the landslide ratio was estimated as $10.7 \%$. The landslide after 2009 centralized in the upstream TRW, especially in the T01 sub-watershed $\left(121.6 \mathrm{~km}^{2}\right)$. The occupied percentage of the landslide cases with area $>100,000 \mathrm{~m}^{2}$, $1000-100,000 \mathrm{~m}^{2}$, and $<1000 \mathrm{~m}^{2}$ to all landslide cases in 2009 in the TRW were $4.2 \%, 71.2 \%$, and $24.6 \%$, respectively. The relation between the landslide length to width ratio and the mean slope in the TRW is shown in Figure 3; 98.1\% and 64.3\% of the landslide cases in 2009 in the TRW were of the landslide length to width ratio > 1.0 and ranged from 1.0 to 5.0. These data show that the majority landslide type of the landslide cases induced by the 2009 Typhoon Morakot in the TRW were rainfall-triggered slides on the steep slope. 

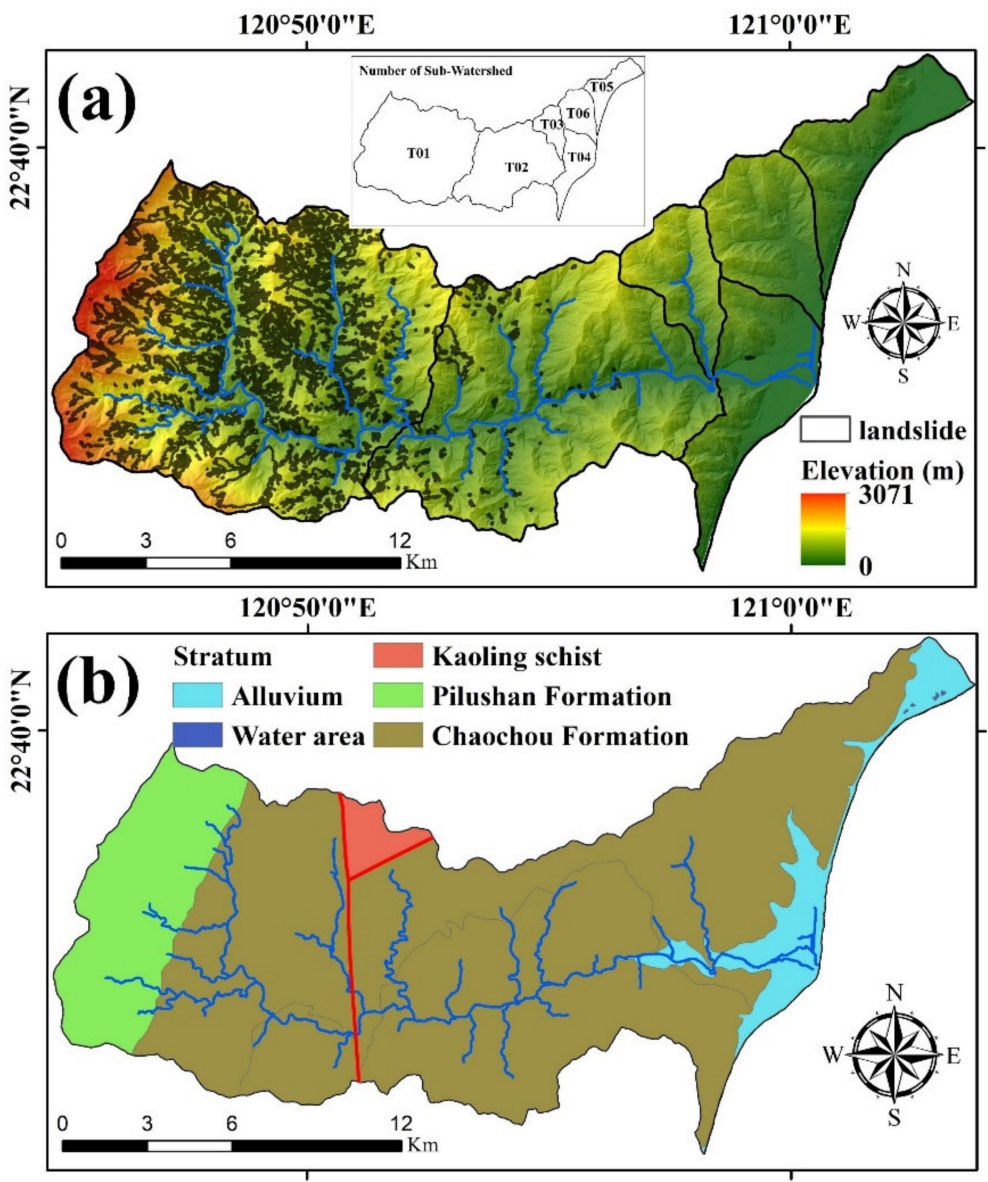

Figure 4. The distribution of elevation, landslide after 2009 Typhoon Morakot, and sub-watersheds (a), geological settings (b) in the TRW.

\section{Data and Methods}

\subsection{Annual Landslide Inventories}

The annual landslide inventories from 2005 to 2015 produced by the Forestry Bureau in Taiwan were used in this study, and the minimum landslide area in the annual landslide inventories was $100 \mathrm{~m}^{2}$. Based on Varnes' classification [19], the majority of the landslide cases induced by 2009 Typhoon Morakot in southern Taiwan were rotational slides, translational slides, and flows [20-22].

\subsection{Effective Accumulated Rainfall Index (EAR)}

The $E A R$ index (unit: $\mathrm{mm}$ ) was used to assess the landslide-induced strength of rainfall events. The $E A R$ index, defined in Equation (1), is the summation of daily rainfall on the assessment day $\left(R_{t}\right)$ and the 7-day antecedent rainfall before the assessment day. The $K$ coefficient, representing the decay constant, was set to 0.7 based on Taiwanese landslide research [23]. Equation (1) is calculated as follows:

$$
E A R_{t}=\sum_{i=0}^{7} R_{t} \times K^{i}
$$

The rainfall records used to estimate the EAR index value were collected from the representative rainfall stations at watersheds. For inclusion, the representative rainfall stations had to be located within the watershed, and the rainfall records from 2005 to 2015 had to be available without any missing data. The representative rainfall stations in the two watersheds are Ali station in the ARW and Jinfong station in the TRW. The annual landslide inventories were used in this study. It is challenging to find data on the time and 
date of landslide occurrences and estimate the rainfall threshold to induce the landslide. Rather than determining the precise time and date of landslide occurrences, the $E A R$ values used in this study serve as reference coefficients to understand the intensity of landslides induced by typhoons and other heavy rainfall events each year from 2005 to 2015 .

\subsection{Landslide Topographic Position Analysis}

The topographic position analysis method can be used to explain the main inducing factors of landslides [24]. Three parameters of the landslide on the hillslope, including the distance between the ridge and the crown of the landslide $\left(D_{P}\right)$, the distance between the stream and the toe of the landslide $\left(D_{B}\right)$, and the distance between the ridge of the hillslope and river $\left(D_{H}\right)$, are used to explain the relative location of the landslide in the hillslope. The bubble plot is frequently used to draw the result of the topographic position analysis using the normalized distance from a landslide to the ridge $\left(D_{P} / D_{H}\right)$ as the $\mathrm{X}$-axis, the normalized distance from a landslide to the stream $\left(D_{B} / D_{H}\right)$ as Y-axis, and the size of the bubble as the landslide area. If the bubbles are located in the upper-left portion of the bubble plot $\left(D_{P} / D_{H}<0.5\right.$ and $\left.D_{B} / D_{H}>0.5\right)$, the landslide cases are located near the ridge and possibly induced by earthquake events [24]. If the bubbles are located in the lower-left portion of the bubble plot $\left(D_{P} / D_{H}>0.5\right.$ and $\left.D_{B} / D_{H}<0.5\right)$, the landslide cases are located near the stream and possibly induced by rainfall or flooding events [1,21].

\subsection{Spatiotemporal Cluster Analysis Method}

We used the emerging hot spot analysis in the space-time cluster analysis tool in the ArcGIS Pro software to analyze the landslide evolution and identify the landslide hotspots and cold spots from 2005 to 2015. The emerging hot spot analysis tool can detect eight hotspot or cold spot trends, and the definition of the eight hot spot or cold spot trends had been described in Table 1 (revised from [14]). The emerging hot spot analysis was widely used in observing the evolution of the natural or artificial phenomenon but has still rarely been used to analyze the landslide evolution. The analysis unit in the study is a $5 \mathrm{~m} \times 5 \mathrm{~m}$ grid, and the time step is a year. The clustering intensity of landslide in each analysis unit was estimated using the Getis-Ord Gi statistic [25], which considered the clustering intensity value for each analysis unit within the context of the values for the neighboring analysis unit. In the study, the neighborhood distance of the analysis unit was set as $25 \mathrm{~m}$.

Table 1. The classifications and definition of emerging landslide hot spot and cold spot in the study.

\begin{tabular}{|c|c|}
\hline Classification & Definition \\
\hline $\begin{array}{l}\text { Consecutive } \\
\text { (CHS or CCS) }\end{array}$ & $\begin{array}{l}\text { A landslide location with a single uninterrupted run of statistically significant hot spot or cold spot } \\
\text { areas in the final year during the research time period. The landslide location has never been a } \\
\text { statistically significant hot spot or cold spot before the final hot spot or cold spot run. }\end{array}$ \\
\hline $\begin{array}{l}\text { Diminishing } \\
\text { (DHS or DCS) }\end{array}$ & $\begin{array}{l}\text { A landslide location that has been a statistically significant hot spot or cold spot for } 90 \% \text { of the research } \\
\text { time period, including the final year. In addition, the clustering intensity of landslide in each year is } \\
\text { decreasing (increasing) overall and that decrease (increase) is statistically significant. }\end{array}$ \\
\hline $\begin{array}{l}\text { Historical } \\
\text { (HHS or HCS) }\end{array}$ & $\begin{array}{l}\text { The most recent year is not hot spot or cold spot, but at least } 90 \% \text { of the research time period has been a } \\
\text { statistically significant hot spot or cold spot. }\end{array}$ \\
\hline $\begin{array}{l}\text { Intensifying } \\
\text { (IHS or ICS) }\end{array}$ & $\begin{array}{l}\text { A landslide location that has been a statistically significant hot spot or cold spot for } 90 \% \text { of the research } \\
\text { time period. In addition, the clustering intensity of landslide for each year increased (decreased) } \\
\text { overall and that increase (decrease) was statistically significant. }\end{array}$ \\
\hline $\begin{array}{l}\text { New } \\
\text { (NHS or NCS) }\end{array}$ & $\begin{array}{l}\text { A landslide location identified as a statistically significant hot spot or cold spot since the first year of the } \\
\text { research time period but was not previously identified as a statistically significant hot spot or cold spot. }\end{array}$ \\
\hline $\begin{array}{l}\text { Oscillating } \\
\text { (OHS or OCS) }\end{array}$ & $\begin{array}{l}\text { A statistically significant hot spot or cold spot for the final year that has a history of also being a } \\
\text { statistically significant cold spot or hot spot during a prior year. Less than } 90 \% \text { of the research time } \\
\text { period have been statistically significant hot spot or cold spot. }\end{array}$ \\
\hline
\end{tabular}


Table 1. Cont.

\begin{tabular}{cr}
\hline Classification & Definition \\
\hline $\begin{array}{c}\text { Persistent } \\
\text { (PHS or PCS) }\end{array}$ & $\begin{array}{c}\text { A landslide location that has been a statistically significant hot spot or cold spot for 90\% of the research } \\
\text { time period with no discernible trend indicating an increase or decrease in the clustering intensity of } \\
\text { landslide over time. }\end{array}$ \\
\hline $\begin{array}{c}\text { Sporadic } \\
\text { (SHS or SCS) }\end{array}$ & $\begin{array}{r}\text { A landslide location that is an on-again then off-again hotspot or cold spot. Less than } 90 \% \text { of the } \\
\text { research time period have been statistically significant hot spot or cold spot, and none of the time-step } \\
\text { intervals have been statistically significant colds pot or hot spot. }\end{array}$ \\
\hline
\end{tabular}

No pattern detected (No)

The analysis area does not fit any definition of hot spot or cold spot classifications

Note: The CHS and CCS are the abbreviations of consecutive hot spot and consecutive cold spot. The regulation of abbreviation is applied to each hot spot and cold spot in the study.

\section{Decadal Analyses Results}

\subsection{Rainfall Distribution and Landslide Ratio}

The EAR distributions from 2005 to 2015 in the two watersheds are shown in Figure 5 and Table 2. The average $E A R$ value from 2005 to 2015 was 39.7 in the $A R W$ and 29.7 in the TRW. The highest $E A R$ values $\left(E A R_{h}\right)$ in the $A R W$ and $T R W$ were 1926.9 and 1123.5 on 8 August 2009. The $E A R_{h}$ and $E A R_{a}$ (the average of the three highest $E A R$ values in each year) from 2005 to 2008 in the two watersheds were larger than those from 2010 to 2015. The return periods of the top ten daily rainfall events from 2005 to 2008 in the two watersheds were estimated to be 10-50 years, and those from 2010 to 2015 were estimated to only be $<2$ year. The data demonstrated that the $E A R$ value and the return periods of rainfall events from 2005 to 2008 in the two watersheds were larger than those from 2010 to 2015.

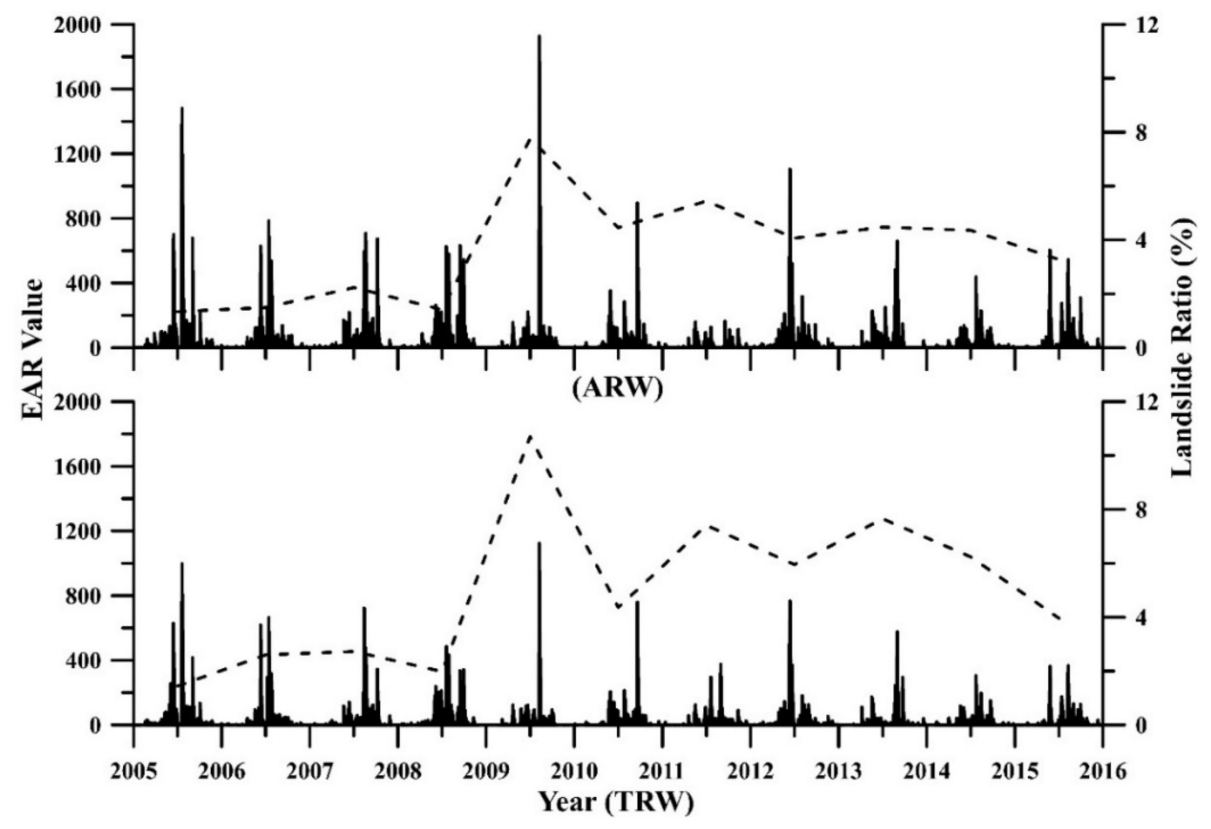

Figure 5. The distribution of effective accumulated rainfall index (abbreviated as EAR) value (black bar) and landslide ratio (dash line) from 2005 to 2015 in the ARW (up figure) and TRW (down figure).

The landslide ratios in 2009 in the $A R W$ and TRW (Figure 5) were their historical peaks. The average landslide ratios in the ARW and TRW from 2005 to 2008 were $1.6 \%$ and 2.2\%, respectively, and those from 2010 to 2015 were $4.3 \%$ and $5.9 \%$, respectively. The trends of the landslide ratios in the two watersheds after 2009 were oscillating instead of stably decaying. The $E A R_{h}$ and $E A R_{a}$ in 2011 and 2013 in the $A R W$ were smaller than those from 2005 to 2007, but the landslide ratio increased in 2011 and 2013. Other similar examples are shown in comparing the $E A R_{h}, E A R_{a}$, and landslide ratios in 2011 and 2013 in the 
TRW. This data implied that landslides were more easily induced after the 2009 Typhoon Morakot. The rainfall factor was possibly not the only landslide-inducing factor in the two watersheds after 2009.

Table 2. The statistical data of the $E A R$ values from 2005 to 2015 in the two watersheds.

\begin{tabular}{|c|c|c|c|c|c|c|c|c|c|c|c|}
\hline Year & 2005 & 2006 & 2007 & 2008 & 2009 & 2010 & 2011 & 2012 & 2013 & 2014 & 2015 \\
\hline \multicolumn{12}{|c|}{ in the $A R W$} \\
\hline$E A R_{h}$ & 1481.7 & 784.8 & 707.2 & 631.9 & 1926.9 & 894.5 & 163.5 & 1104.4 & 658.5 & 438.5 & 609.9 \\
\hline$E A R_{a}$ & 1353.7 & 700.6 & 680.9 & 616.5 & 1755.8 & 697.8 & 150.1 & 943.6 & 587.4 & 340.7 & 551.1 \\
\hline \multicolumn{12}{|c|}{ in the $T R W$} \\
\hline$E A R_{h}$ & 997.0 & 663.4 & 723.1 & 485.2 & 1123.5 & 759.3 & 374.6 & 766.2 & 576.2 & 304.8 & 367.3 \\
\hline$E A R_{a}$ & 856.3 & 620.6 & 593.6 & 449.6 & 944.0 & 588.9 & 332.0 & 670.3 & 494.2 & 250.8 & 351.0 \\
\hline
\end{tabular}

Note: The $E A R_{h}$ means the highest $E A R$ value, and the $E A R_{a}$ means the average of the three highest $E A R$ values in each year.

\subsection{Landslide Statistical Data}

The research period was divided into three periods (i.e., 2005-2008, 2009, and 2010-2015) to analyze the changes in landslide distribution before and after 2009. The landslides' statistical data from 2005 to 2015 in the two watersheds are shown in Figure 6 and Table 3. The area and number of landslides from 2010 to 2015 in the two watersheds were larger than those from 2005 to 2008. From 2005 to 2015, the year with the most landslides was 2009 , but the year with the most landslide numbers was 2013. In the $A R W$, for example, the landslide area in 2013 was $42 \%$ smaller than that in 2009, but the landslide number in 2013 was 31\% higher than that in 2009. The same trend was observed in 2013 in the TRW. This data implies that most of the landslides induced by 2009 Typhoon Morakot gradually recovered, but some new landslides occurred in the two watersheds in 2013.

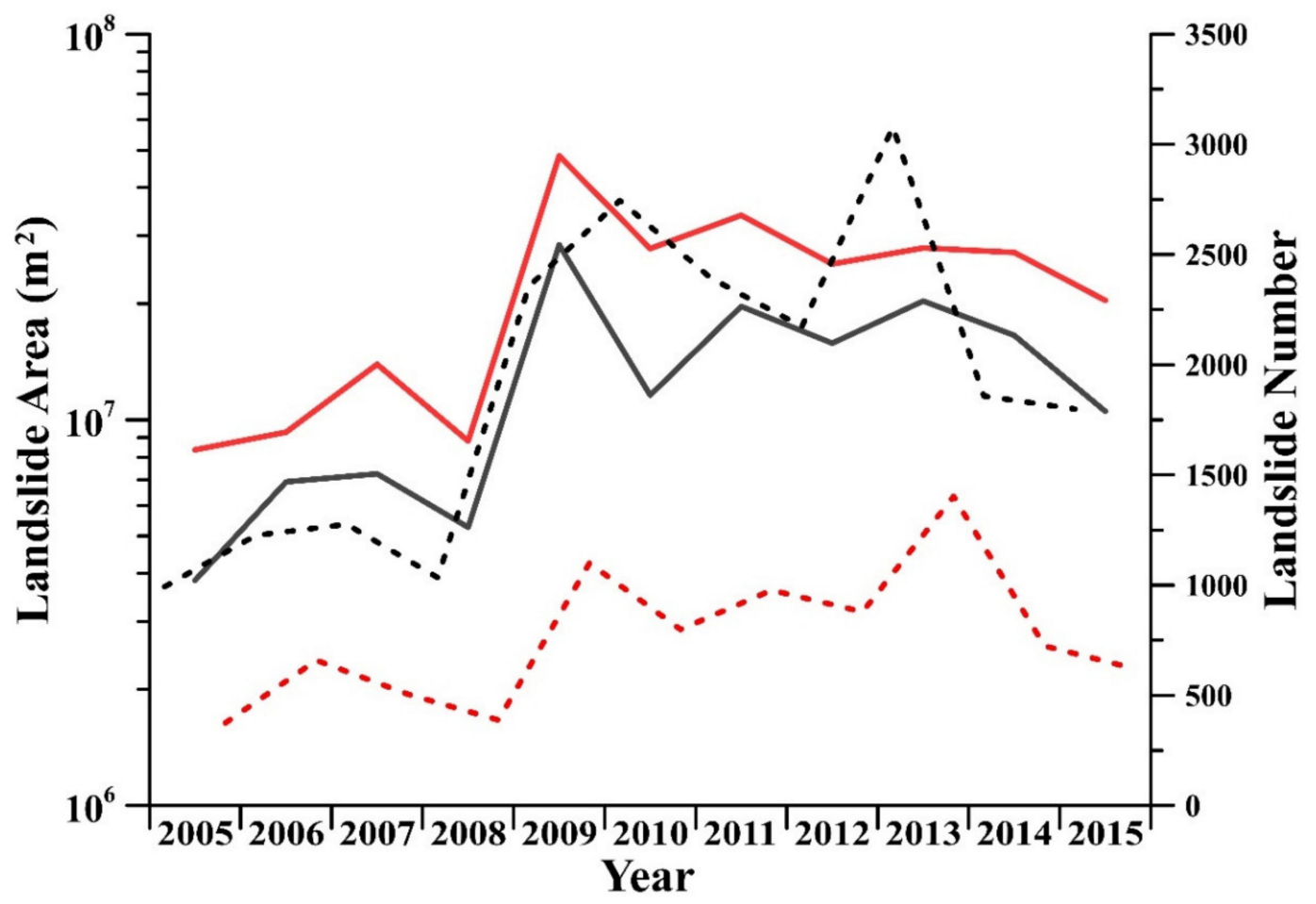

Figure 6. The area (solid line) and number (dash line) of landslide in the ARW (black) and TRW (red) from 2005 to 2015.

This study analyzed the landslide distribution at the sub-watershed scale to find the sub-watersheds in which landslides were induced in the years following the 2009 Typhoon Morakot. The landslide evolution trend index (abbreviated as LET) in this study was 
defined as the average change ratio of the landslide area from 2010 to 2015, and the LET was estimated in each sub-watershed of the two watersheds (Figure 7). A negative LET value indicates that the total landslide area in this sub-watershed gradually decreases, while a positive $L E T$ value indicates that the total landslide area gradually increases. The average $L E T$ value in the sub-watersheds was -0.022 and $-0.072 \mathrm{~km}^{2} /$ year in the ARW and TRW.

Table 3. The average area and number of landslides in the two watersheds.

\begin{tabular}{cccccc}
\hline & Year & 2005 to 2015 & 2005 to 2008 & 2009 & 2010 to 2015 \\
\hline \multirow{2}{*}{ ARW } & Average landslide area $\left(\mathrm{km}^{2}\right)$ & 22.8 & 10.1 & 48.4 & 27.1 \\
& Average landslide number & 1902.8 & 1132.3 & 2355 & 2341.2 \\
\hline \multirow{2}{*}{ TRW } & Average landslide area $\left(\mathrm{km}^{2}\right)$ & 13.3 & 5.8 & 28.4 & 15.8 \\
& Average landslide number & 766.3 & 482.0 & 1100 & 900.2 \\
\hline
\end{tabular}
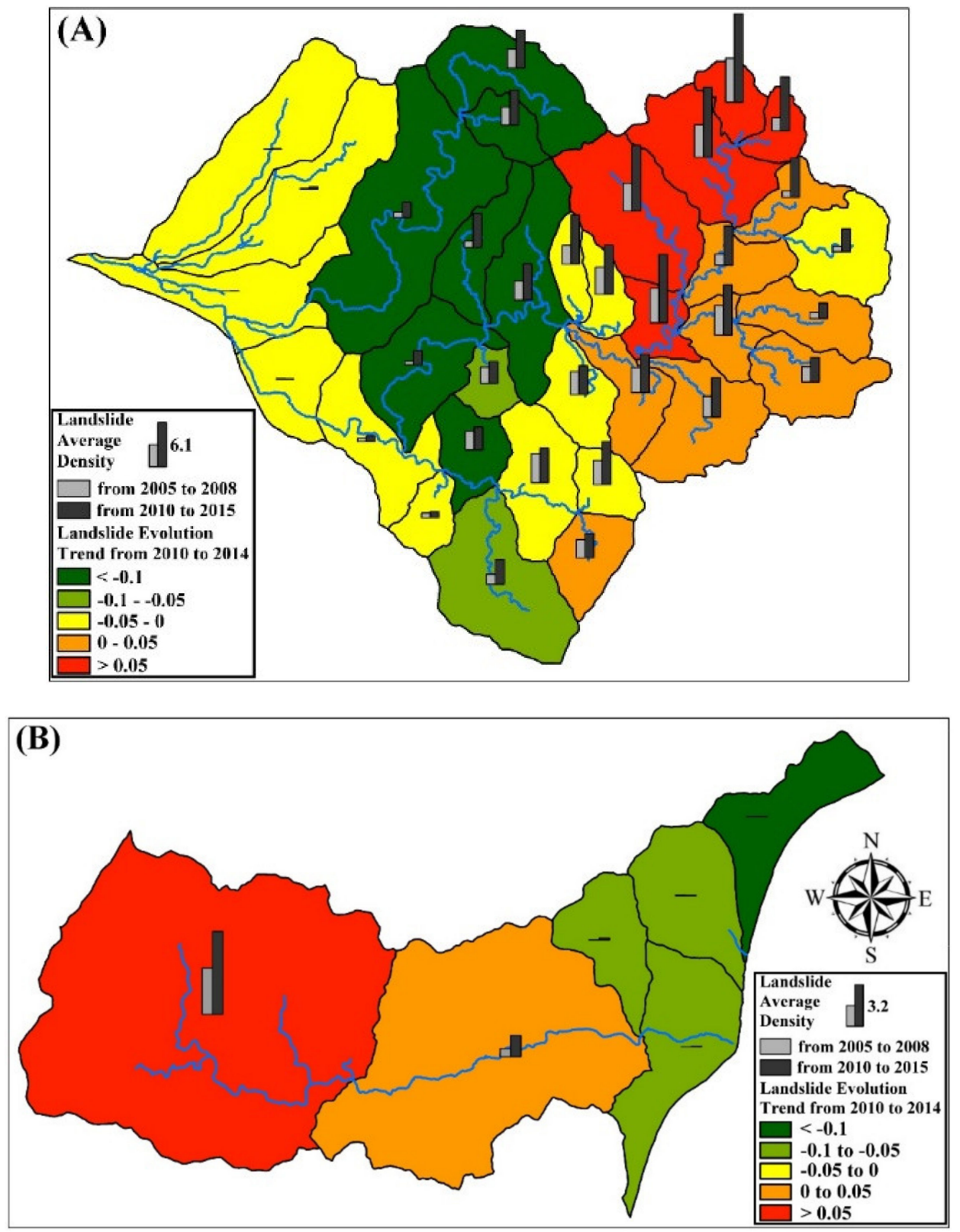

Figure 7. The average landslide density and landslide evolution trend index value from 2005 to 2015 in the $A R W$ (A) and TRW (B). 
The sub-watersheds with positive $L E T$ values were located upstream of $A R W$ and $T R W$. There were 13 and 2 sub-watersheds with the positive $L E T$ values in the $A R W$ and $T R W$, respectively, and the landslide ratio of the 15 sub-watersheds after 2009 was larger than $4.4 \%$. There were six sub-watersheds with the LET values $>0.05$, including A01, $\mathrm{A} 02, \mathrm{~A} 03, \mathrm{~A} 07$, and $\mathrm{A} 11$ in the $A R W$ and T01 in the TRW, and the landslide ratio of the six sub-watersheds after 2009 was greater than 12.1\%. The watershed areas in the A01, A02, A03, A07, A11, and T01 sub-watersheds were 8.2, 6.7, 24.7, 31.7, 9.5, and $121.6 \mathrm{~km}^{2}$, respectively, and the landslide ratios after the 2009 Typhoon Morakot were $27.8 \%, 21.2 \%$, $26.2 \%, 21.5 \%, 12.1 \%$, and $20.7 \%$, respectively. These results imply that the landslides in the sub-watersheds with a landslide ratio of $>4.4 \%$ after 2009 in the $A R W$ and TRW were difficult to recover and were easily induced or re-induced from 2010 to 2015.

\subsection{Landslide Topographic Position Analysis}

The study used the landslide topographic position analysis to examine the landslide evolution before and after 2009 in the ARW and TRW. The A03 (LET = $\left.0.32 \mathrm{~km}^{2} / \mathrm{y}\right), \mathrm{A} 31$ $\left(L E T=-0.31 \mathrm{~km}^{2} / \mathrm{y}\right)$, and T01 $\left(L E T=0.43 \mathrm{~km}^{2} / \mathrm{y}\right)$ sub-watersheds were selected for comparison of landslide evolution before and after 2009 (Table 4 and Figures 8 and 9). The area in the A31 sub-watershed was $33.9 \mathrm{~km}^{2}$, and the landslide area and landslide ratio in 2009 in the A31 sub-watershed were $2.8 \mathrm{~km}^{2}$ and $8.3 \%$. The ratio of landslide area from 2009 to 2015 in the upslope, mid-slope, and downslope were $19.4 \%, 25.5 \%$, and $38.2 \%$, respectively, in the $A R W$ and $27.6 \%, 29.8 \%$, and $31.1 \%$ in the $T R W$, respectively. The landslide located in the downslope was the most difficult to recover from 2009 to 2015 in the slope.
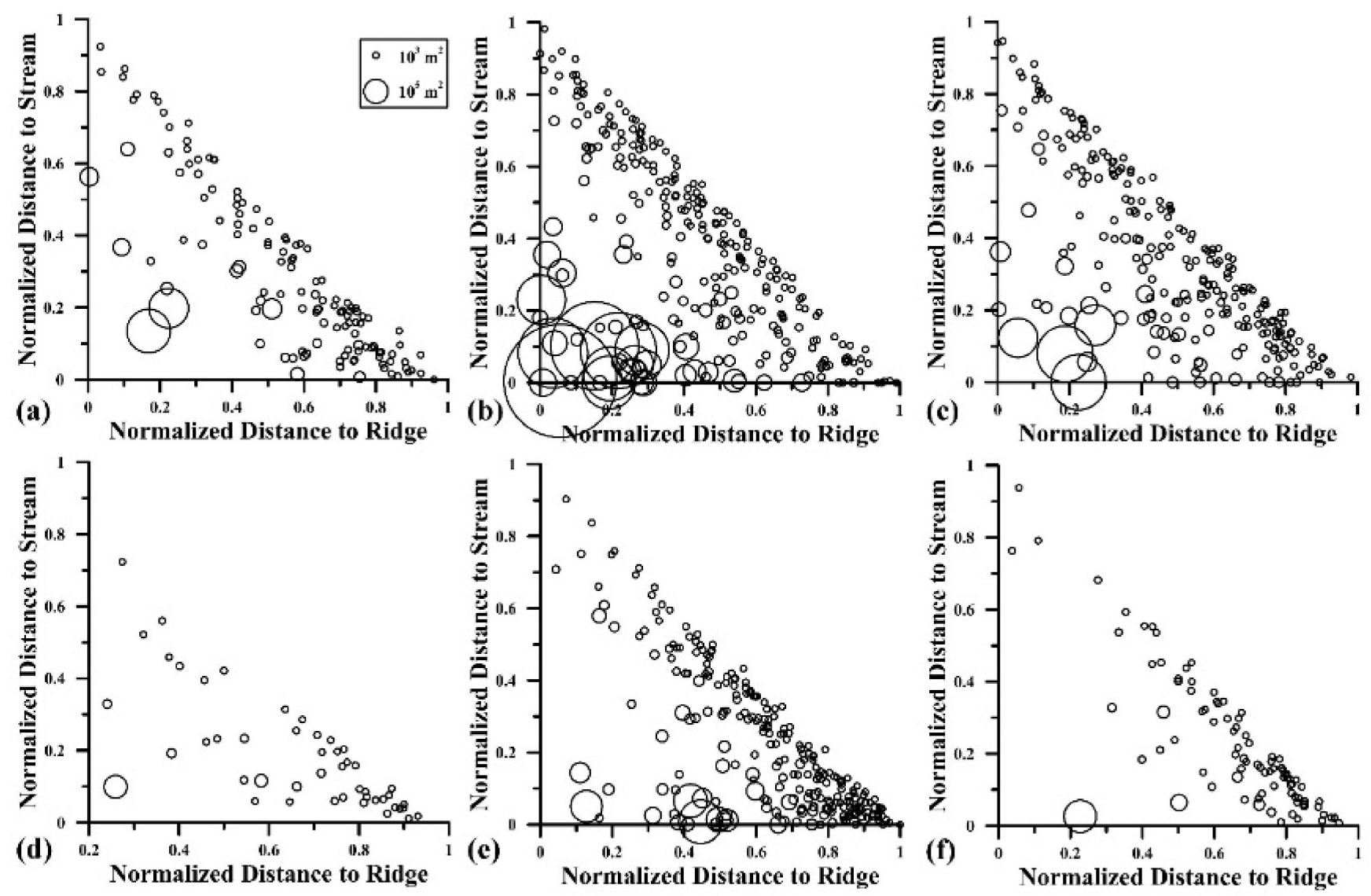

Figure 8. The topographic position analysis of landslide in 2008 (a-d), 2009 (b-e), and 2015 (c-f) in the A03 (up figures) and A31 (down figures) subwatersheds in the $A R W$. 
Table 4. The topographic position analysis results in the ARW and TRW.

\begin{tabular}{|c|c|c|c|c|c|c|c|c|c|c|c|c|}
\hline Time & B & 2009 & A & 2015 & B & 2009 & A & 2015 & B & 2009 & A & 2015 \\
\hline & \multicolumn{4}{|c|}{ ARW } & \multicolumn{4}{|c|}{ A03 sub-watershed } & \multicolumn{4}{|c|}{ A31 sub-watershed } \\
\hline UA & 4.64 & 13.56 & 3.69 & 2.63 & 0.13 & 0.29 & 0.28 & 0.21 & 0.01 & 0.13 & 0.04 & 0.02 \\
\hline MA & 0.81 & 2.39 & 2.20 & 0.61 & 0.76 & 5.27 & 2.88 & 1.92 & 0.15 & 1.31 & 0.48 & 0.21 \\
\hline DA & 2.49 & 12.16 & 5.37 & 4.65 & 0.36 & 0.74 & 0.64 & 0.59 & 0.24 & 1.22 & 0.5 & 0.28 \\
\hline & \multicolumn{4}{|c|}{ TRW } & \multicolumn{4}{|c|}{ T01 sub-watershed } & & & & \\
\hline UA & 2.05 & 4.78 & 3.37 & 1.32 & 0.09 & 0.23 & 0.2 & 0.15 & & & & \\
\hline MA & 0.38 & 3.19 & 1.09 & 0.95 & 0.45 & 4.76 & 0.03 & 0.01 & & & & \\
\hline DA & 1.59 & 5.92 & 2.56 & 1.84 & 0.37 & 1.11 & 0.9 & 0.76 & & & & \\
\hline
\end{tabular}

Note: "B" and "A" mean that the average landslide area before 2009, i.e., from 2005 to 2008 and after 2009, i.e., from 2010 to 2015. UA, MA, and DA mean the upslope, mid-slope, and downslope landslide area $\left(\mathrm{km}^{2}\right)$.
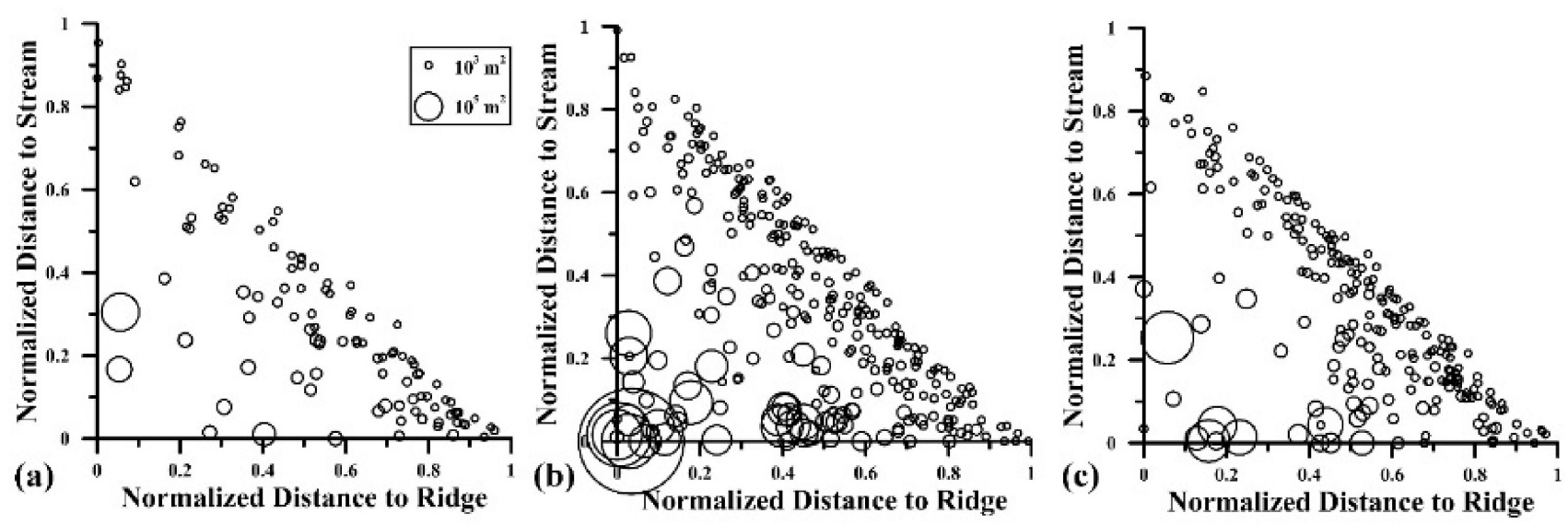

Figure 9. The topographic position analysis of landslide in 2008 (a), 2009 (b), and 2015 (c) in the T01 sub-watershed in the TRW.

A similar trend was also found in the A03, A31, and T01 sub-watersheds. The ratio of landslide area from 2009 to 2015 in the downslope was $79.7 \%, 23.0 \%$, and $68.5 \%$ in the A03, A31, and T01 sub-watersheds, respectively. Figures 8 and 9 show that a reduction was observed in the number of upslope, mid-slope, and downslope landslides in the subwatersheds, but the landslides in 2015 were concentrated in the downslope area. From 2009 to 2015, a large cluster of small-area landslides occurred downslope in the sub-watersheds, with poor recovery. Most of the landslides in the A03 and T01 sub-watersheds in 2015 were centered in areas with a normalized distance to a ridge of $>0.7$, meaning that the inducing factors should be related to the bank-erosion landslide, which was possibly induced by the sinuous rivers with huge amounts of deposited sediment.

\subsection{Spatiotemporal Landslide Hotspot Analysis}

The landslide ratios in the ARW and TRW after 2009 were $7.6 \%$ and $10.7 \%$, and those were the top two highest landslide ratios in the watershed scale in Taiwan. It is interesting to understand the evolution of numerous landslides and compare the characteristic of landslide distribution before and after 2009 in the two watersheds. The evolutions of the landslide from 2005 to 2015 in the $A R W$ and TRW were observed from the spatiotemporal landslide hotspot analyses (Table 5 and Figure 10) in the study.

The total areas from 2010 to 2015 in the two watersheds are 1.15-2.23 times larger than those from 2005 to 2008, and the increases in the landslide hot spot areas from before to after 2009 in the two watersheds were evident. The landslide hot spot areas from 2010 to 2015 in the two watersheds are 2.67-2.88 times larger than those from 2005 to 2008, and the landslide cold spot area is 1.73-1.93 times larger. This result means that the total time of areas identified as landslides from 2010 to 2015 is longer than that from 2005 to 2008 . The 
landslide recovery was more difficult, and the landslide was easier to be clustered after than before 2009 Typhoon Morakot.

Table 5. The statistical data of spatiotemporal landslide hot spots and cold spots in the ARW and TRW.

\begin{tabular}{ccccccc}
\hline Watershed & ARW & & TRW & \\
\hline year & $05-15$ & $05-08$ & $10-15$ & $05-15$ & $05-08$ & $10-15$ \\
\hline HS $\left(\mathrm{km}^{2}\right)$ & 17.6 & 7.8 & 22.5 & 8.8 & 4.8 & 12.8 \\
CS $\left(\mathrm{km}^{2}\right)$ & 13.5 & 10.3 & 20.3 & 6.8 & 5.5 & 9.5 \\
No $\left(\mathrm{km}^{2}\right)$ & 35.1 & 4.6 & 8.1 & 20.3 & 2.3 & 4.9 \\
Total $\left(\mathrm{km}^{2}\right)$ & 66.2 & 22.8 & 50.9 & 35.9 & 12.6 & 27.1
\end{tabular}

Note: The 05-15, 05-08, and 10-15 mean from 2005 to 2015, from 2005 to 2008, and from 2010 to 2015. The HS and CS mean the total area of all hot spots and cold spots, and the NO means the no pattern detected area.

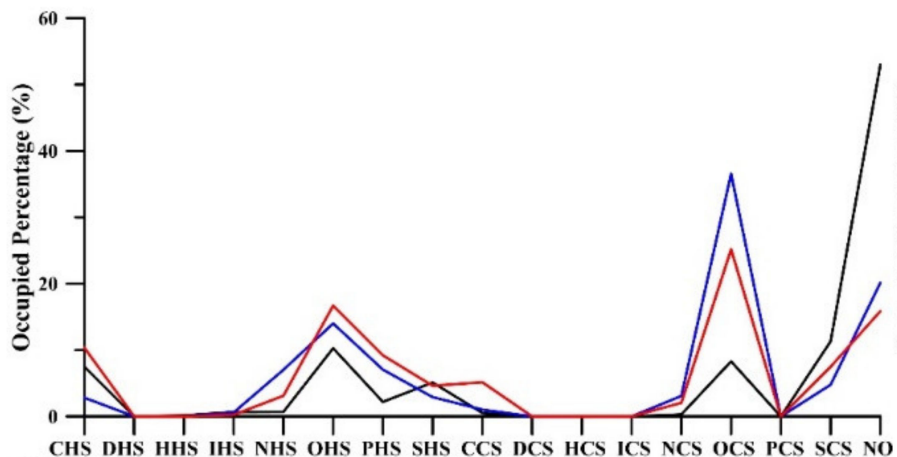

(a)

Hot and Cold Spots

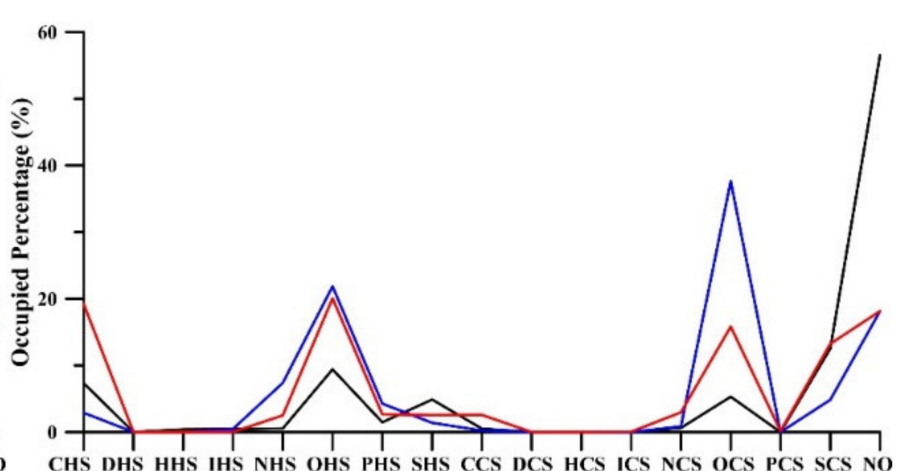

(b)

Hot and Cold Spots

Figure 10. The occupied percentage of landslide hot spots and cold spots from 2005 to 2015 (black line), from 2005 to 2008 (blue line), from 2010 to 2015 (red line), and in the ARW (a) and TRW (b).

The no pattern detected area means that the time of area identified as a landslide is shorter than $90 \%$ of the research period (Table 1). The occupied percentages of the no pattern detected areas from 2005 to 2015 in the two watersheds are $53.0-56.5 \%$, but those from 2005 to 2008 and from 2010 to 2015 are only $15.9 \%$ to $20.2 \%$. This data means that $36.3-37.1 \%$ of landslide areas in the two watersheds recovered to the non-landslide areas in 4 to 9 years.

The landslide hot spots are centralized in OHS, SHS, and CHS in each research period, while the landslide cold spots are centralized in OCS, CCS, and SCS. The landslide hot spots and cold spots were reclassified into the main hot spots, the main cold spots, no pattern detected, and others. The main hot spots included OHS, SHS, and CHS, the main cold spots included OCS, CCS, and SCS, and the others included all the other hot spots and cold spots except the main hot spots and cold spots. After 2009, the main hot spots constituted 34.0-41.9\% of all hot spots, whereas the main cold spots accounted for $31.6-37.8 \%$ of all cold spots.

Figures 11 and 12 present the main hot spots and cold spots from 2005 to 2015 in the two watersheds. The upstream sub-watersheds with dense landslide distributions were the main hot spot cluster areas in the two watersheds.

The main hot spots from 2005 to 2008 were discretely distributed in the upstream sub-watersheds of $A R W$ and TRW, and those from 2010 to 2015 were densely clustered in the upstream of $A R W$ and TRW, particularly in the A01 and T01 sub-watersheds.

Obvious increases in the average landslide ratios from after to before the 2009 Typhoon Morakot in the two watersheds were noted. The CHS were the hot spots that exhibited the largest area expansion from after to before the 2009 Typhoon Morakot, and the OCS were the cold spots that exhibited the largest area reduction. The CHS percentage increased by $7.5 \%$ to $16.3 \%$ from after to before the 2009 Typhoon Morakot, and the OCS percentage decreased from $11.4 \%$ to $21.8 \%$. This means that the recovery of landslides induced by 2009 Typhoon Morakot was slower than that before 2009. 

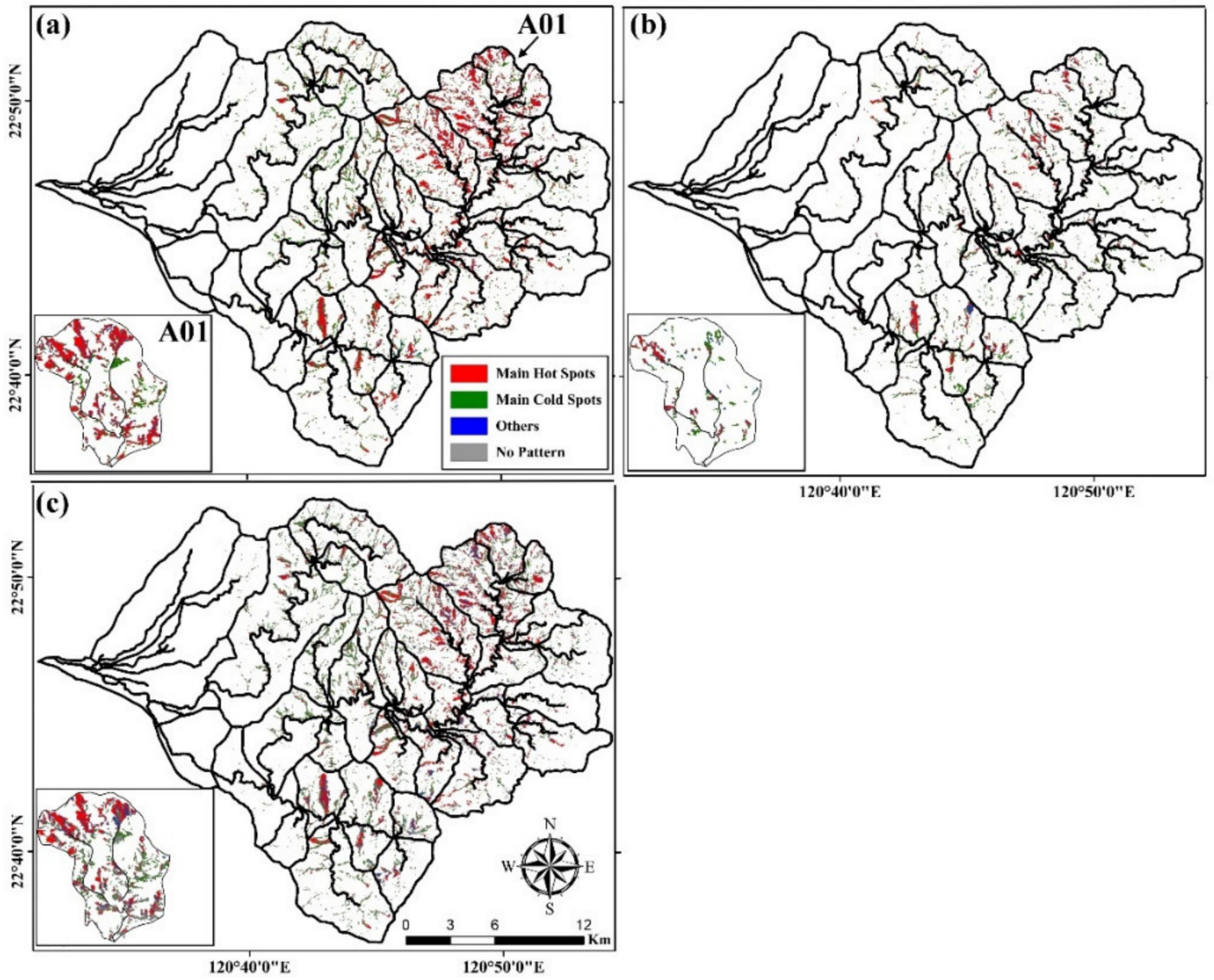

$120^{\circ} 40^{\circ} 0^{\prime \prime E}$

$120^{\circ} 50^{\circ} 0^{\prime \prime} \mathrm{E}$

Figure 11. The main landslide hot spot and cold spot from 2005 to 2015 (a), from 2005 to 2008 (b), and from 2010 to 2015 (c) in the $A R W$.
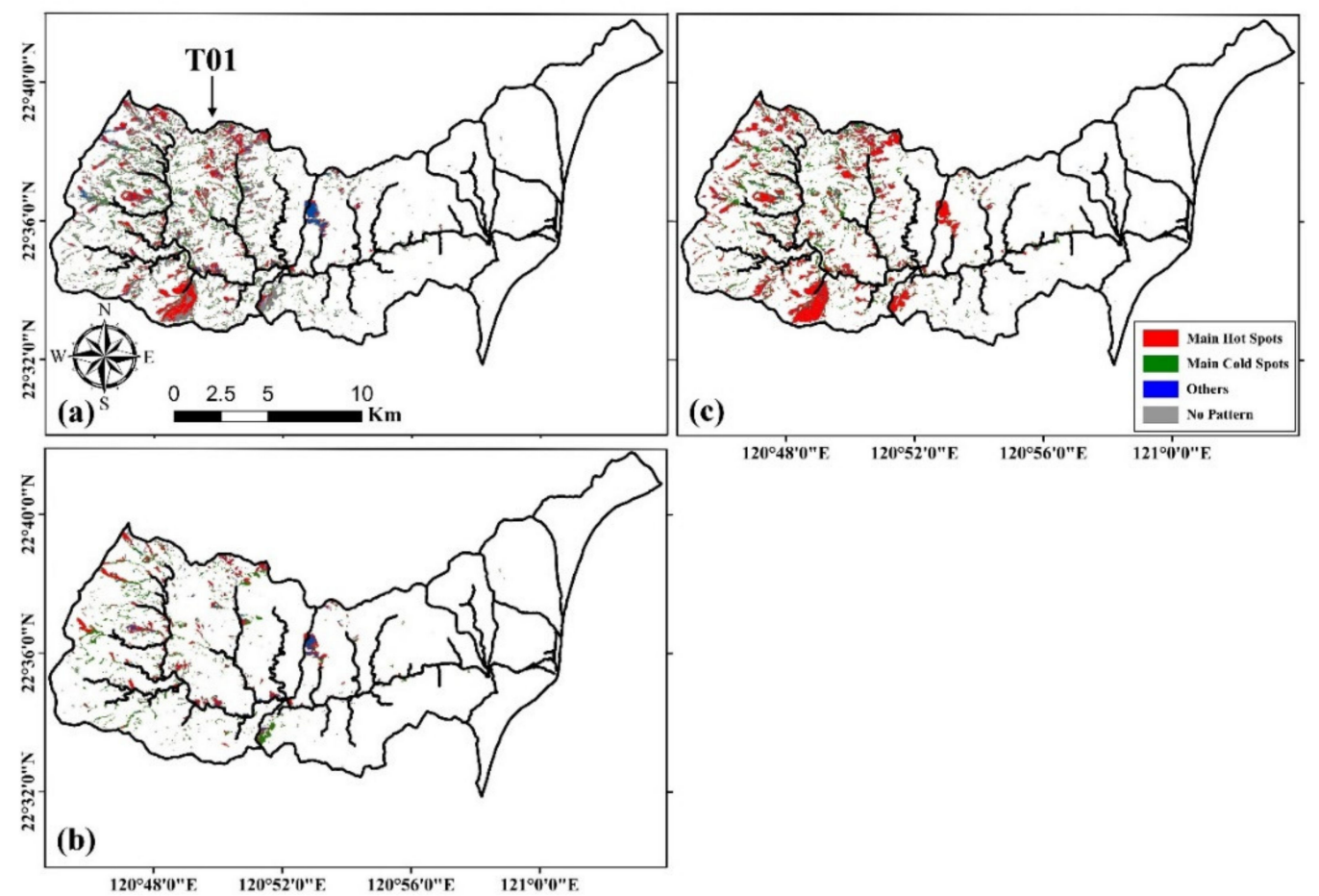

$120^{\circ} 48^{\circ} 0^{\prime \prime} \mathrm{E} \quad 120^{\circ} 52^{\prime} 0^{\prime \prime} \mathrm{E} \quad 120^{\circ} 56^{\prime} 0^{\prime \prime E} \quad 121^{\circ} 0^{\prime} 0^{\prime \prime}$

Figure 12. The main landslide hot spot and cold spot from 2005 to 2015 (a), from 2005 to 2008 (b), and from 2010 to 2015 (c) in the TRW. 
The A01 sub-watershed was selected as the representative sub-watershed to explain the distribution of the main hot spots and cold spots in the study. The strata in A01 comprise the Pilushan and Chaochou formations (62.6\% and 37.4\%, respectively) from the Eocene epoch and Middle Miocene sub-epoch, respectively. The lithology of the Pilushan formation comprises slate with metasandstone and igneous rock, whereas that of the Chaochou formation is argillite and slate with an alternation of metasandstone or argillite. The main hot spots and main cold spots in the A01 sub-watershed increased substantially after Typhoon Morakot. From 2005 to 2008, 2010 to 2015, and 2005 to 2015, the main hot spots in the A01 sub-watershed constituted 3.0\%, 17.0\%, and 12.5\%, respectively, and the main cold spots constituted 3.8\%,5.9\%, and 4.2\%, respectively. The main hotspots from 2010 to 2015 in the A01 sub-watershed were concentrated in the headwater landslides, bank-erosion landslides in sinuous reaches, and reoccurrence of older (from 2005 to 2008) landslides.

Mechanisms and triggering factors of landslide events, landslide areas with poor recovery, and geomorphological evolution trends can be explained, located, and predicted using the distributions of landslide hot spots and cold spots that were constructed through spatiotemporal analysis. The results of the spatiotemporal analysis over the various periods have different implications. Specifically, the hot spot and cold spot distributions from 2005 to 2015, from 2005 to 2008, and from 2010 to 2015 in the ARW and TRW represent the long-term landslide evolution.

\section{Discussion}

The prediction of landslide recovery in watersheds with dense landslides could be the key factor for watershed management. The characteristic of landslide recovery in the following years after the large earthquake or extreme rainfall events are worth comparing and discussing. We explained the recovery characteristic of extreme rainfall-induced landslides by comparing the landslide recovery conditions after the 2005 Kashmir earthquake [5], the 2008 Wenchuan earthquake [4,9], and the 2009 Typhoon Morakot in this study. The time, location, and rate of landslide recovery after the large earthquake or extreme rainfall events are the key discussion topics in this study.

The oscillating period was observed after the large earthquake or extreme rainfall events based on the annual landslide area data. The oscillating period can be defined as that the annual landslide area and landslide number in this period is an oscillating trend instead of a stable decline trend. The oscillating period for the serious earthquake-induced landslide events ranged from 3 to 5 years. The extreme rainfall-induced landslide events in the study were estimated as 5 years (Figure 4 and Table 6, from 2010 to 2014). The landslide in the watersheds in the oscillating period was active and easily induced, re-induced, or enlarged. The average annual landslide area decline rates (abbreviated as $L A D$ ) after 2014 were larger than that during the oscillating period (from 2010 to 2014), and the average $L A D$ during or after the oscillating period in this study was also larger than those from the large earthquake-induced landslide events. This means that the recovery rate of the extreme rainfall-induced landslide was faster than that of large earthquake-induced landslide.

Table 6. Comparison of the average annual landslide area decline rate from the large earthquake events and the extreme rainfall events.

\begin{tabular}{cccc}
\hline Events & Oscillating Period & LAD $_{\mathbf{O}} \mathbf{( k m}^{2} /$ Year) & LAD $_{\mathbf{A}}\left(\mathbf{k m}^{\mathbf{2}} /\right.$ Year) \\
\hline 2005 Kashimir Earthquake & $2005-2010$ & 0.32 & 0.99 \\
2008 Wenchuan Earthauke & $2008-2011$ & 0.41 & 0.96 \\
2009 Typhoon Morakot (ARW) & $2009-2014$ & 4.24 & 6.78 \\
2009 Typhoon Morakot (TRW) & $2009-2014$ & 2.37 & 6.04 \\
\hline
\end{tabular}

Note: LAD means the average annual landslide area decline rate $\left(\mathrm{km}^{2} /\right.$ year $)$, and $\mathrm{LAD}_{\mathrm{O}}$ and $\mathrm{LAD}_{\mathrm{A}}$ mean the LAD during the oscillating period and after the oscillating period.

The location and reason of new or enlarged landslides after the large earthquake or extreme rainfall events are worth discussing and comparing. The new or enlarged land- 
slides in the following years after the 2005 Kashimir earthquake (including the active, very active, and extremely active landslides in [5]) were mostly located along the Muzaffarabad fault or in the high fractured and jointed rocks areas, or along with the drainage network, or in the source of the river and large landslide. Moreover, the new or enlarged landslides in the following years after the 2008 Wenchuan earthquake (the active landslides in [4]) were located in deep gullies, the source of debris flow and large landslides. Three factors, including the geological setting, the drainage network, and the landslide area, dominate the rate of landslide recovery after 2009 in the $A R W$ and TRW in the study.

The statistical data and distribution of landslide evolution in the ARW and TRW are shown in Table 7 and Figure 13. The new or enlarged landslide in the following years after 2009 centralized in the northeast $A R W$ and upstream TRW. The strata in the northeast $A R W$ comprise $62.6 \%$ Pilushan formation (metasandstone and igneous rock) and $37.4 \%$ Chaochou formations (argillite and slate with an alternation of metasandstone or argillite), and three faults and anticlines also pass through the northeast ARW. The strata in the upstream TRW comprise the Chaochou formations (sandstone), kaolinite schist, and Pilushan formations (metasandstone and igneous rock), and three faults and anticlines also pass through the northeast TRW. Fractured slate, sandstone, or argillite are the main geological composition in the northeast $A R W$ and upstream $T R W$, and also explain the reasons for the centralization of new or enlarged landslides in this area.

Table 7. Statistical data of landslide evolution from 2009 to 2010, 2013, and 2015 in the ARW.

\begin{tabular}{ccccccc}
\hline \multirow{2}{*}{ Landslide Types } & \multirow{2}{*}{ R Area } & NR Area & \multicolumn{3}{c}{ NE } \\
\cline { 4 - 7 } & & & Area & Gully-Related & River-Related & Large-Related \\
\hline $2009-2010$ & 24.8 & 23.5 & 4.3 & 2.41 & 0.02 & 1.34 \\
$2009-2013$ & 26.1 & 22.2 & 5.7 & 3.07 & 0.05 & 1.84 \\
$2009-2015$ & 28.1 & 20.2 & 7.2 & 4.04 & 0.08 & 2.54 \\
\hline
\end{tabular}

Note: The unit of area in this table is $\mathrm{km}^{2}$. R, NR, and NE mean the recovered, not recovered, and new and enlarged landslide, and the gully-related, river-related, and large-related mean the NE landslide located in the neighborhood of gully, river, and large landslide.

The landslide evolution results from the comparison of landslide inventories in two different years can be classified into three types, including recovered landslides, not recovered landslides, and new or enlarged landslides (Figure 13). The recovered landslide area from the comparison between 2009 and 2010 (Table 7) was the area identified as landslide in 2009 but not in 2010, and the not recovered landslide area were the areas identified as landslide in 2009 and 2010. The new or enlarged landslide area was the area identified as landslide in 2010 but not in 2009. The new or enlarged landslide in the $A R W$ and TRW also centralized along with the drainage network, particularly in the upstream watersheds. Hugh sediment yield from the landslide in the upstream watershed with dense landslide should be the main reason. The landslide volume was estimated the empirical equations from Taiwan [26] for the landslide area $<10^{6} \mathrm{~m}^{2}$ and Italy [27] for the landslide area $\geqq 10^{6} \mathrm{~m}^{2}$ ]. The landslide volume induced by 2009 Typhoon Morakot was estimated as $65.0 \times 10^{6} \mathrm{~m}^{3}$ and $224.5 \times 10^{6} \mathrm{~m}^{3}$ in the $A R W$ and TRW. There were 848 landslide cases after 2009 in the northeast upstream $A R W$, including A01, A02, A03, A07, and A11 sub-watersheds, and 1138 landslide cases in the upstream TRW, i.e., the T01 sub-watershed. The landslide volume was estimated as $5.2 \times 10^{6} \mathrm{~m}^{3}$ in the northeast upstream of the $A R W$ and $223.9 \times 10^{6} \mathrm{~m}^{3}$ in the T01 sub-watershed. Huge sediment was yielded, deposited in the narrow reaches, and dominated the evolution of landslide and river geomorphology in the northeast $A R W$ and upstream TRW.

Huge sediment in the upstream watershed was continuously transported into the gullies and rivers and also resulted in the frequent occurrence of new or enlarged landslides in the neighborhood of gullies and rivers from 2010 to 2015 in the ARW. Moreover, 51.3\%, $54.0 \%$, and $58.2 \%$ of the landslide areas after 2009 in the ARW had been recovered in 2010, 2013, and 2015, respectively. The new or enlarged landslide area from 2010 to 2015 in the $A R W$ showed a continuously increasing trend. The occupied percentage of a 
new or enlarged landslides located in the neighborhood of gullies from 2010 to 2015 was $53.9-56.1 \%$, and the area of a new or enlarged landslide located in the neighborhood of the river from 2010 to 2015 also showed an increasing trend.
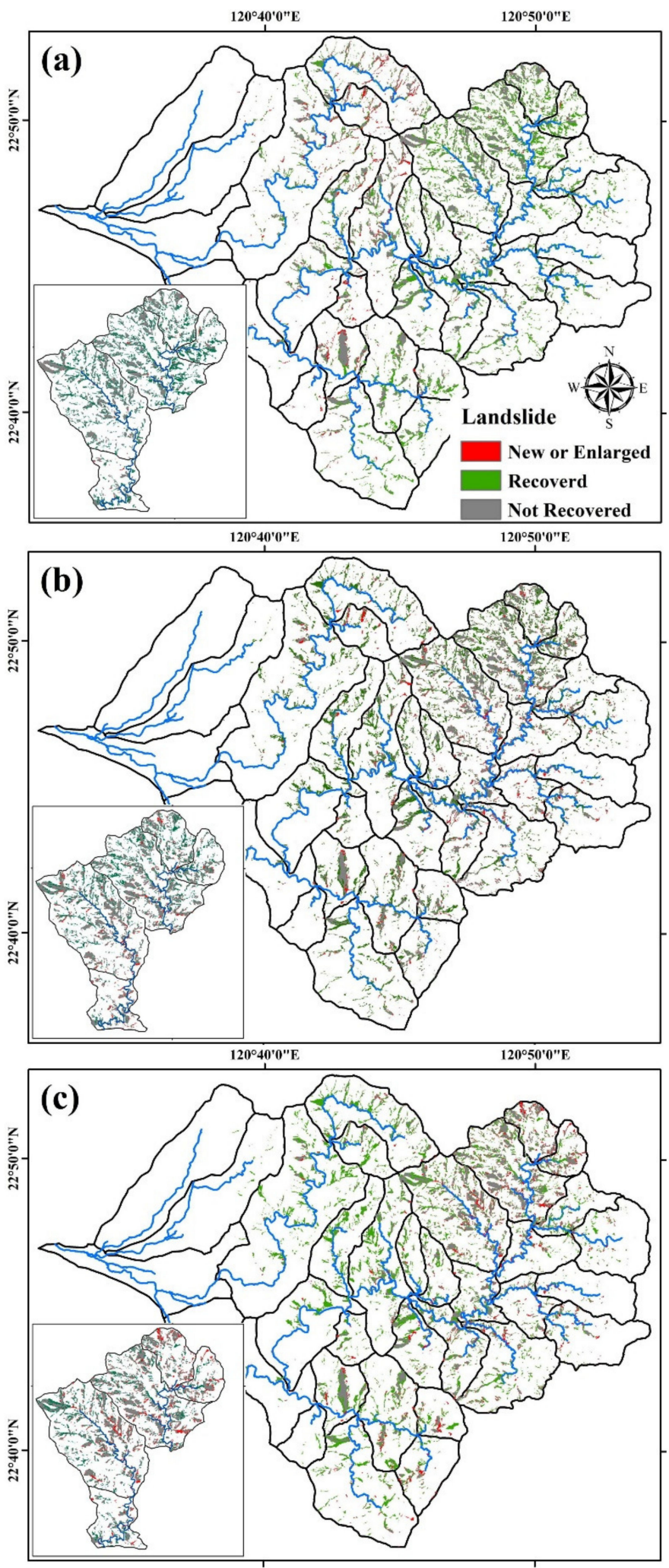

Figure 13. The landslide evolution from 2009 to 2010 (a), to 2013 (b), and to 2015 (c) in the ARW. The left down plot in each figure is the landslide evolution in the northeast $A R W$, including the A01, A02, A03, A07, and A11 sub-watersheds. 
The centralization of new or enlarged landslides in the neighborhood of large landslides was mentioned $[4,5]$, and it was also observed in the study. The occupied percentage of a new or enlarged landslide located in the neighborhood of large landslide cases from 2010 to 2015 in the $A R W$ was 31.2-35.3\%, particularly in the northeast $A R W$.

The dentification of landslide hot spots using the emerging hot spot analysis in this study can show the clustering strength of old, new, and enlarged landslides in space and time and provide a potential landslide location. The advantage of the identification of landslide hot spots using the emerging hot spot analysis is that we can estimate the maintenance time of landslides from the classification of landslide hot spots, and this information also contributes to making the priority of watershed management measures in the watersheds with dense landslides. The management strategy for the watersheds with huge sediment yield should be implemented considering the landslide evolution trend. The landslide evolution cases in the ARW and TRW in Taiwan demonstrated that controlling the sediment in the drainage network and the landslide boundary should be the priority after the extreme rainfall-induced landslide events.

\section{Conclusions}

This study used the rainfall analysis, spatiotemporal landslide hotspot analyses, and comparison analysis of large earthquake- and extreme rainfall-induced landslide evolution to understand the characteristic of rainfall-induced landslide evolution, which was useful in assessing the landslide activeness after an extreme rainfall event. We used the $E A R$ to assess the landslide-induced strength of rainfall events from 2005-2015, and the $E A R$ values in the $A R W$ and TRW were larger than before after the 2009 Typhoon Morakot. The landslide evolution trend index (LET) was used to assess the recovery ratio of landslide area after 2009, and the $L E T$ value in most of the sub-watersheds in the $A R W$ and TRW were ranged $0.022-0.072 \mathrm{~km}^{2} /$ year. However, some sub-watersheds in the $A R W$ and TRW, particularly in the upstream watershed with the landslide ratio $>4.4 \%$, were still of $L E T$ value $>0.05 \mathrm{~km}^{2} /$ year after 2009 . The landslides downslope of subwatersheds with positive $L E T$ values in the $A R W$ and TRW after 2009 were easily induced, re-induced, or enlarged and difficult to recover based on the landslide topographic position analysis. Most of the new or enlarged landslides in the ARW and TRW after 2009 were classified into oscillating or sporadic or consecutive landslide hotspots and centralized along with the drainage network or large landslide boundary. The watersheds with dense landslides needed to spend 3-5 years, i.e., the oscillating period in the study, to achieve the stable landslide recovery based on the comparison of landslide recovery after the large earthquake or extreme rainfall events. The landslide area decline rates in the $A R W$ and TRW after 2009 were 1.6-2.5 times larger after than during the oscillating period. The new or enlarged landslides after 2009 in the $A R W$ and TRW was centralized in the huge sediment-deposited, narrow, and sinuous reaches or the boundary of a large landslide in the upstream watersheds with a geological composition of fractured slate, sandstone, or argillite. The findings from the study point out that the watershed management strategies in the watershed with dense landslides after the extreme rainfall-induced landslide events should be emphasized to control the huge sediment yield from the numerous landslides, particularly in the upstream watersheds.

Author Contributions: Conceptualization and methodology, C.W. and C.L.; software, C.L.; writing, C.W. and C.L.; supervision and funding acquisition, C.W. Both authors have read and agreed to the published version of the manuscript.

Funding: This work was supported by Ministry of Science and Technology, Taiwan; Grant number: MOST 108-2625-M-035-003-(Taiwan).

Institutional Review Board Statement: Not applicable.

Informed Consent Statement: Not applicable.

Data Availability Statement: Not applicable. 
Acknowledgments: Financial supports from the Ministry of Science and Technology of Taiwan (R.O.C.) under contract MOST 108-2625-M-035-003- are appreciated.

Conflicts of Interest: The author declares no conflict of interest.

\section{References}

1. Wu, C.-H.; Chen, S.-C.; Chou, H.-T. Geomorphologic characteristics of catastrophic landslides during typhoon Morakot in the Kaoping Watershed, Taiwan. Eng. Geol. 2011, 123, 13-21. [CrossRef]

2. Wu, C.-H.; Chen, S.-C.; Feng, Z.-Y. Formation, failure, and consequences of the Xiaolin landslide dam, triggered by extreme rainfall from Typhoon Morakot, Taiwan. Landslides 2013, 11, 357-367. [CrossRef]

3. Feng, Z.-Y. The seismic signatures of the surge wave from the 2009 Xiaolin landslide-dam breach in Taiwan. Hydrol. Process. 2011, 26, 1342-1351. [CrossRef]

4. Li, J.; Wang, N.; Wang, J.; Li, H. Spatiotemporal evolution of the remotely sensed global continental PM2.5 concentration from 2000-2014 based on Bayesian statistics. Environ. Pollut. 2018, 238, 471-481. [CrossRef] [PubMed]

5. Shafique, M. Spatial and temporal evolution of co-seismic landslides after the 2005 Kashmir earthquake. Geomorphology 2020, 362, 107228. [CrossRef]

6. Yunus, A.P.; Fan, X.; Tang, X.; Jie, D.; Xu, Q.; Huang, R. Decadal Vegetation Succession from MODIS Reveals the Spatio-Temporal Evolution of Post-Seismic Landsliding after the 2008 Wenchuan Earthquake. Remote Sens. Environ. 2020, 236, 111476. [CrossRef]

7. $\mathrm{Wu}, \mathrm{C}$. Landslide Susceptibility Based on Extreme Rainfall-Induced Landslide Inventories and the Following Landslide Evolution. Water 2019, 11, 2609. [CrossRef]

8. Valenzuela, P.; Domínguez-Cuesta, M.J.; Mora García, M.A.; Jiménez-Sánchez, M. A Spatial-Temporal Landslide Inventory for the NW of Spain: BAPA Database. Geomorphology 2017, 293, 11-23. [CrossRef]

9. Liu, S.H.; Lin, C.W.; Tseng, C.M. A Statisticalmodel for the Impact of the 1999 Chi-Chi Earthquake on the Subsequent Rain-fallInduced Landslides. Eng. Geol. 2013, 156, 11-19. [CrossRef]

10. Tang, C.; Jiang, Z.; Li, W. Seismic Landslide Evolution and Debris Flow Development: A Case Study in the Hongchun Catchment, Wenchuan Area of China. Eng. Geol. Soc. Territ. 2015, 2, 445-449. [CrossRef]

11. Zhang, S.; Zhang, L. Impact of the 2008 Wenchuan earthquake in China on subsequent long-term debris flow activities in the epicentral area. Geomorphology 2017, 276, 86-103. [CrossRef]

12. Yang, W.; Qi, W.; Wang, M.; Zhang, J.; Zhang, Y. Spatial and temporal analyses of post-seismic landslide changes near the epicentre of the Wenchuan earthquake. Geomorphology 2017, 276, 8-15. [CrossRef]

13. ESRI. [WWW Document]. Doc. ArcGIS. 2018. Available online: https://pro.arcgis.com/en/pro-app/tool-reference/analysis/ enrich-layer.htm (accessed on 15 May 2021).

14. Barboza, G.E.; Schiamberg, L.B.; Pachl, L. A spatiotemporal analysis of the impact of COVID-19 on child abuse and neglect in the city of Los Angeles, California. Child. Abus. Negl. 2021, 116, 104740. [CrossRef]

15. Cheng, Z.; Zu, Z.; Lu, J. Traffic Crash Evolution Characteristic Analysis and Spatiotemporal Hotspot Identification of Urban Road Intersections. Sustainability 2018, 11, 160. [CrossRef]

16. Nielsen, C.; Amrhein, C.G.; Shah, P.S.; Stieb, D.M.; Osornio-Vargas, A.R. Space-time hot spots of critically ill small for gestational age newborns and industrial air pollutants in major metropolitan areas of Canada. Environ. Res. 2020, 186, 109472. [CrossRef]

17. Lin, S.C.; Ke, M.C.; Lo, C.M. Evolution of landslide hotspots in Taiwan. Landslides 2017, 14, 1491-1501. [CrossRef]

18. Shou, K.-J.; Lin, J.-F. Evaluation of the extreme rainfall predictions and their impact on landslide susceptibility in a sub-catchment scale. Eng. Geol. 2020, 265, 105434. [CrossRef]

19. Varnes, D.J. Introduction to Landslides: Analysis and Control; Transportation and Road Research Board; National Academy of Science: Washington, DC, USA, 1978; pp. 11-33.

20. Lu, S.Y.; Lin, C.Y.; Hwang, L.S. Spatial Relationships between Landslides and Topographical Factors at the Liukuei Experi-mental Forest, Southwestern Taiwan after Typhoon Morakot. Taiwan J. For. Sci. 2011, 26, 399-408.

21. Wu, C.Y.; Tsai, C.W.; Chen, S.C. Topographic Characteristic Analysis of Landslides in Kaoping River Watershed. J. Chin. Soil Water Conserv. 2016, 47, 156-164. (In Chinese)

22. Lin, Y.T.; Chang, K.C.; Yang, C.J. Object-Based Classification for Detecting Landslides and Vegetation Recovery-A Case at Baolai, Kaohsiung. J. Chin. Soil Water Conserv. 2018, 49, 98-109. (In Chinese)

23. Chen, C.-W.; Saito, H.; Oguchi, T. Analyzing rainfall-induced mass movements in Taiwan using the soil water index. Landslides 2016, 14, 1031-1041. [CrossRef]

24. Meunier, P.; Hovius, N.; Haines, J.A. Topographic site effects and the location of earthquake induced landslides. Earth Planet. Sci. Lett. 2008, 275, 221-232. [CrossRef]

25. Getis, A.; Ord, J.K. The Analysis of Spatial Association by Use of Distance Statistics. Geogr. Anal. 2010, 24, 189-206. [CrossRef]

26. Chan, H.C.; Chang, C.C.; Chen, S.C.; Wei, Y.S.; Wang, Z.B.; Lee, T.S. Investigation and Analysis of the Characteristics of Shallow Landslides in Mountainous Areas of Taiwan. J. Chin. Soil Water Conserv. 2015, 46, 19-28. (In Chinese)

27. Guzzetti, F.; Ardizzone, F.; Cardinali, M.; Galli, M.; Reichenbach, P.; Rossi, M. Distribution of landslides in the Upper Tiber River basin, central Italy. Geomorphology 2008, 96, 105-122. [CrossRef] 